Revista Mídia e Cotidiano

Artigo Seção Livre

ISSN 2178-602X

Volume 15, Número 3, set-dez/2021

Submetido em: 23/02/2021

Aprovado em: 09/08/2021

\title{
Negacionismo em textos acadêmicos no Portal de Periódicos Capes
}

\author{
Negationism in academic texts in the Portal de Periódicos Capes
}

\section{Negacionismo en textos académicos en el Portal de Periódicos Capes}

\author{
Marcello Mattos de CARVALHO ${ }^{1}$ \\ Carlos A. ZANOTTI ${ }^{2}$
}

\section{Resumo}

Este trabalho parte de uma discussão sobre o crescente uso da expressão negacionismo na imprensa ou em debates acadêmicos publicados na mídia - para investigar a produção científica, em língua portuguesa, sobre a presença do termo em textos indexados no Portal de Periódicos da Capes. Com origem no desejo de negar uma verdade para aplacar aflições individuais, a expressão nasceu na psicanálise freudiana, e hoje designa conduta de caráter coletivo. $\mathrm{O}$ estudo aqui proposto adota pesquisa bibliográfica, estratégias bibliométricas e técnicas de análise de conteúdo visando apurar recortes e conceitos acolhidos nos estudos recuperados daquele banco de dados. O resultado aponta a existência de apenas seis trabalhos indexados no Portal, todos publicados entre os anos de 2009 e 2020, inexistindo produções que insiram negacionismo no campo midiático.

Palavras-chave: Sociedade midiatizada. Negacionismo. Revisionismo. Ciência. Notícias falsas.

\begin{abstract}
This work is part of a discussion about the growing use of the term negationism, either in the press or in academic debates published in the media, to investigate the scientific production about the use of the term in the Portal de Periódicos Capes, in Portuguese. Originating in the desire to deny a truth to appease individual afflictions, the expression was born in Freudian psychoanalysis, today designating conduct of a collective character. For the study proposed, bibliographic research, bibliometric strategies and content analysis techniques are adopted in order to ascertain cuttings and concepts accepted in the studies retrieved from that database. The result points to the existence of only six indexed works on the Portal, all published between the years 2009 and 2020, with no productions that insert negationism in the media field.
\end{abstract}

\footnotetext{
1 Jornalista e mestrando do PPG em Linguagens, Mídia e Arte, da PUC-Campinas. E-mail: marcellomcarvalho@gmail.com. ORCID: 0000-0002-0789-3329.

2 Professor e pesquisador da Faculdade de Jornalismo e do PPG em Linguagens, Mídia e Arte, da PUCCampinas. E-mail: zanotti@puc-campinas.edu.br. ORCID: 0000-0002-6644-7206.
} 
Keywords: Mediatized society; Negationism; Revisionism; Science; Fake news.

\section{Resumen:}

Este trabajo es parte de una discusión sobre el uso creciente del término negacionismo sea en la prensa o en debates académicos publicados en los medios de comunicación para investigar la producción científica, en portugués, sobre el uso del término en el Portal de Periódicos Capes. Con origen en el deseo de negar una verdad para apaciguar las aflicciones individuales, la expresión nació en el psicoanálisis freudiano, hoy designando una conducta de carácter colectivo. Para el estudio que aquí se propone se utilizan investigación bibliográfica, estrategias bibliométricas y se adoptan técnicas de análisis de contenido para conocer los esquemas y conceptos aceptados en los estudios recuperados de esa base de datos. El resultado apunta a la existencia de solo seis trabajos indexados en el Portal, todos publicados entre los años 2009 y 2020, sin producciones que inserten el negacionismo en el ámbito midiático.

Palabras-clave: Sociedad mediatizada. Negacionismo. Revisionismo. Ciencia. Noticias falsas.

\section{Introdução}

A pandemia da Covid-19, tema naturalmente associado à saúde pública, acabou se transformando também em um problema de comunicação, de natureza políticoideológica, perpassando o sistema de mídia como um todo. Médicos e especialistas em virologia ligados a centros de pesquisa e de controle sanitário ganharam a atenção das mídias tradicionais, enquanto outros atores sociais encontraram na tragédia a matériaprima ideal e o ambiente propício para explorar a crença de incautos e disseminar a desinformação. Competindo com o trabalho mediador historicamente orquestrado pelo sistema de mídia - e graças às ferramentas comunicacionais disponíveis na rede de computadores - o negacionismo do conhecimento científico ganhou densidade e se instalou no evento pandêmico em dimensões ainda não apuradas e pouco exploradas nos estudos acadêmicos.

Conforme aponta Gomes (2021), uma parte considerável do drama humano vivido durante a propagação do vírus começou com a própria politização da pandemia por parte de organizações mundiais associadas à direita radical. Dois fatores teriam contribuído para tanto: o surgimento do vírus em uma nação associada à doutrina comunista, na cidade de Wuhan (China), e o fato de ter se espalhado "justo no momento 


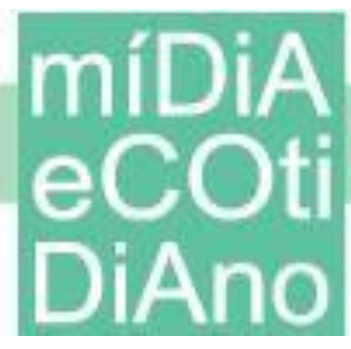

de máxima expansão de governos e movimentos de extrema direita no mundo" (GOMES, $2021, \mathrm{n} / \mathrm{p})$.

No sistema de mídia, o surgimento do novo coronavírus obrigou os meios de comunicação a ampliarem o léxico com que informam e comentam acontecimentos do e para o tecido social. Inicialmente, além de recorrerem ao universo lexical das ciências naturais, por onde transita o jornalismo científico, a mídia tradicional se viu na contingência de também agregar expressões criadas na área de humanidades para dar informações e orientar condutas, adotando verbetes como "isolamento", "distanciamento social", "média móvel [de contaminados e mortos]" e "achatamento da curva". Posteriormente - em função da politização da crise sanitária - a imprensa também popularizou a expressão negacionismo, até então rarissimamente utilizada em notícias e reportagens.

Embora a palavra não tenha surgido e nem decorrido da pandemia de 2020, o recurso à expressão tornou-se tão comum, nos últimos tempos, a ponto de ser guindada à condição de manchete de um dos principais jornais brasileiros. Na edição do dia 27 de novembro de 2020, O Estado de S. Paulo levou para o alto de sua primeira página uma advertência retirada do discurso de vitória do prefeito então eleito para a cidade de São Paulo, Bruno Covas: "RESTAM POUCOS DIAS PARA O NEGACIONISMO" ("RESTAM..., 2020, p. 1). Mais que endossar a afirmação do político do PSDB - o que ficou evidenciado pelas letras maiúsculas, raramente adotadas em títulos de capas de jornais diários - o tradicional periódico paulistano levava ao principal espaço de sua vitrine a expressão que ganhou densidade editorial em publicações jornalísticas apenas nos últimos anos.

O verbete, que descreve rejeição a evidências incontestáveis, teve seu auge de utilização no Brasil no momento em que o presidente Jair Bolsonaro comparou a Covid19 a "uma gripezinha" (HISTERIA..., 2021), apesar das advertências contrárias da Organização Mundial de Saúde (OMS) e do número de mortes registradas até aquele momento em países europeus. Negacionismo, antes de ocupar o espaço nobre na edição do Estadão, já frequentava espaços discretos em jornais, revistas e emissoras de rádio e televisão. Na internet, a expressão era observada em memes, figurinhas, posts e em alguns circuitos intelectuais posicionados em bolhas. 
Diante da intensificação do uso midiático do verbete - e de sua prática associada à radicalização ideológica de viés conservador - nosso trabalho teve por objetivo apurar o volume de artigos acadêmicos sobre o tema, em língua portuguesa, disponibilizados no Portal de Periódicos Capes (Coordenação de Aperfeiçoamento de Pessoal de Nível Superior). Uma vez recuperados, os textos foram analisados segundo suas autorias, centros de estudo aos quais pertencem os pesquisadores signatários e a base bibliográfica que sustenta tais produções indexadas naquele banco de dados, no qual é possível o acesso a mais de 45 mil títulos com textos completos recolhidos de 130 diferentes bases referenciais.

O levantamento apontou que - apesar da relevância do tema para os estudos de processos comunicacionais no contexto brasileiro contemporâneo - eram poucos os trabalhos desenvolvidos por estudiosos e centros de pesquisa nacionais até então indexados naquela base de dados. Neste sentido, nosso objetivo é contribuir para superar uma lacuna nos estudos de mídia, o locus privilegiado para a atuação dos negacionistas do conhecimento científico no tempo presente. Estimulados pela vaidade pessoal ou por interesses inconfessáveis, eles encontram na lógica dos algoritmos das redes sociais o terreno fértil para desqualificar a ciência e comprometer o regime democrático.

\section{Método}

O trabalho aqui desenvolvido partiu de uma pesquisa bibliográfica e documental, junto a periódicos científicos e no próprio sistema de mídia, com o objetivo de contextualizar o emprego da expressão negacionismo e observar os debates fomentados no meio acadêmico no momento histórico em que o termo ganhava as primeiras páginas de jornais brasileiros. O passo seguinte foi realizar um levantamento, em 3 de novembro de $2020^{3}$, utilizando a expressão "negacionismo" como termo exclusivo de busca no portal criado e mantido pela Capes desde o ano 2000.

3 É possível que uma nova busca indique ter havido alguma alteração no volume de dados obtidos para a realização desta pesquisa, tendo em vista que, nos últimos meses, observa-se, na área de comunicação, a crescente produção de artigos sobre negacionismo do conhecimento científico, motivados pela recente crise sanitária e política registrada no Brasil. 
No total, a ferramenta disponibilizada pelo sistema recuperou 109 documentos, muitos dos quais em língua espanhola em função da mesma grafia, mas apenas 5 artigos e um livro em língua portuguesa. Aos textos recuperados em língua portuguesa, aplicamos estratégias oriundas da bibliometria (MARICATO, 2010) e da análise de conteúdo (FRANCO, 2012). No primeiro caso, chegamos aos autores, áreas de conhecimento, centros de estudo aos quais estão vinculados, número de citações obtidas junto aos pares e base bibliográfica mencionada. No segundo caso, através da análise de conteúdo, buscamos apurar de que forma aparece conceituada a expressão utilizada na busca, o que foi obtido a partir da seleção de excertos específicos para esta finalidade.

\section{Origem na psicanálise}

Segundo apontam os dicionários, o substantivo negacionismo, que deriva do francês negationnisme, com o mesmo sentido, descreve a ideologia "da pessoa que nega ou não aceita um fato comprovado e documentado, analisando esse fato com argumentos ou pontos de vista sem fundamentos históricos" (NEGACIONISMO, 2020a), podendo também ser utilizado em relação ao conhecimento científico. A expressão é utilizada também para indicar "a rejeição da validade de conceitos apoiados por consenso científico ou empiricamente verificáveis", bem como para descrever "a posição de quem nega a existência de um facto documentado ou de quem propõe interpretações não fundamentadas de fenômenos históricos já estudados" (NEGACIONISMO, 2020b). Além de descrever a rejeição a um acontecimento ou conceito, a expressão carrega implícitas as chamadas posturas revisionistas - aquelas que propõem uma narrativa diferente de consensos estabelecidos por historiadores. No caso do jornal paulistano, a manchete referia-se ao contingente de brasileiros que, sob a liderança do presidente Jair Bolsonaro, negavam o conhecimento científico que advertia para a existência da pandemia, uma enfermidade respiratória que, até aquele momento, já havia levado à morte cerca de 170 mil brasileiros, ou 1,5 milhão de habitantes do planeta.

Quando da publicação da manchete no centenário Estadão, uma busca nas indexações do acervo do jornal revelou que, até àquela edição, o termo "negacionismo" havia sido indexado apenas 168 vezes em seu banco de dados. Já no acervo da concorrente Folha de S.Paulo, ele aparecia em 373 indexações no mesmo período de busca. Segundo 


\section{míDiA

o buscador do Google Trends, o interesse pelo termo no Brasil começou a crescer em março de 2020, atingindo o pico no mês de maio, quando declinou, voltando a subir no início de outubro do mesmo ano (GOOGLE TRENDS, 2021a). A mesma ferramenta apontou os verbetes "ciência", "coronavírus" e "negacionismo histórico" como sendo os principais temas associados à palavra, bem como o próprio nome "Jair Bolsonaro" e a expressão "aquecimento global”. Em todo o mundo, a expressão em língua inglesa "denialism" teve pico de busca igualmente no ano de 2020, entre 8 e 14 de novembro. Até àquele momento, os usuários da internet que mais pesquisaram a expressão eram as populações da Austrália, Nova Zelândia, África do Sul, Suécia e Canadá, países onde o negacionismo esteve associado às questões climáticas. Na lista mundial de buscas pela expressão, o Brasil apareceu em $12^{\circ}$ lugar (GOOGLE TRENDS, 2021b).

Acolhendo os pressupostos de Luhmann (2005), antes de ser registrado pelos meios de comunicação, um determinado tema da atualidade - neste caso, a expressão negacionismo - sobressai primeiro no interior dos chamados sistemas de função que compõem o tecido social. Na condição de operadores-difusores do sistema social, os meios de comunicação observam as comunicações ali realizadas para, então, comunicálas aos seus públicos. Inseridos em outros sistemas, esses públicos acabam por disseminar a informação jornalística no sistema social como um todo. Entende-se, portanto, que os sistemas focados em pensar o momento presente (educacional, sanitário, jurídico, político etc.) já observavam que comportamentos negacionistas ganhavam peso naquele período histórico, com implicações que - na avaliação de $O$ Estado de $S$. Paulo - eram dotados de densidade editorial de interesse público. Confirmava-se, assim, um dos pressupostos de Luhmann:

Aquilo que sabemos sobre nossa sociedade, ou mesmo sobre o mundo no qual vivemos, o sabemos pelos meios de comunicação. Isso vale não apenas para nosso conhecimento da sociedade e da história, mas também para nosso conhecimento da natureza. (LUHMANN, 2005, p. 15)

No mesmo sentido da proposição luhmanniana caminham as ponderações de Meditsch (1997), ao defender a ideia de que as operações do jornalismo resultam em uma 


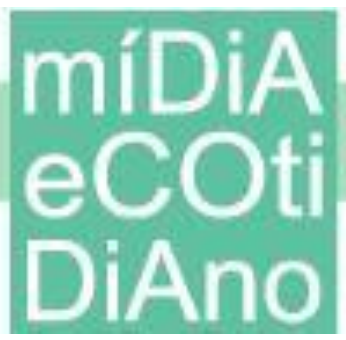

forma efetiva de produção de conhecimento levado ao tecido social. "É inegável que os meios de comunicação têm um poder muito grande no meio social, mas é difícil determinar até que ponto este poder é exercido de forma autônoma e até que ponto funciona apenas como instrumento de outros poderes instituídos" (MEDITSCH, 1997, p. 11). Enquanto produto social, segundo o autor, o jornalismo reproduz o jogo de forças da sociedade em que está inserido. No caso da manchete do Estadão, o jornal penhorava sua influência e credibilidade por três razões: advertir para uma polarização, já que onde há negacionistas há também os não negacionistas; situar-se entre os atores sociais que se baseiam no conhecimento científico, até porque seu ramo de atividade tem o Iluminismo enquanto norte de bússola (SOUSA, 2008, p. 88-97); e para comungar com as esperanças de Covas de que condutas consideradas inadequadas à boa organização sistêmica do tecido social deixariam de prosperar.

Conforme relata o pesquisador Christian Dunker, a expressão negacionismo tem origem na psicanálise, onde o verbete "negação" foi usado pelo neurologista e psiquiatra Sigmund Freud (1856-1939) para descrever atitudes humanas "diante de realidades que são mais dolorosas ou complexas do que conseguimos aguentar" (DUNKER, 2020). No caso brasileiro - mas não apenas no Brasil - uma conduta inicialmente associada a uma patologia individual passou a descrever também uma conduta de caráter coletivo. Essa conduta alcançou dimensões políticas que se referem a um modo de governar, baseado na produção contínua de inimigos imaginários e impactado durante a pandemia do novo coronavírus pela chegada de um inimigo real, biológico e natural. A estratégia governista para arregimentar apoio popular, segundo Dunker, foi lançar dúvida sobre a competência das autoridades científicas, buscando transferir para si a autoridade simbólica até então representada por instituições como a universidade, a imprensa e a ciência. Seria, assim, um método discursivo no qual a crença que as pessoas têm nas instituições desloca-se para a autoridade pessoal do governante.

Na obra Os Assassinos da Memória (1988), o historiador e intelectual francês de origem judia Pierre Vidal-Naquet associa negacionismo às políticas revisionistas no campo da história. No trabalho, ele aponta que políticas revisionistas - sem base comprobatória - correspondem a uma falsificação histórica, o que sempre esteve no horizonte, por exemplo, dos que negam a existência do Holocausto. 
Vidal-Naquet (1988) aponta que o conceito associado ao revisionismo histórico surgiu na Europa, mais precisamente na França. Teria sido na livraria e editora parisiense "A Velha Toupeira", de orientação anarcomarxista, o local de criação das primeiras publicações do gênero. Naquele momento, negacionismo implicava a tentativa de redução do número de judeus vitimados na Segunda Guerra Mundial, para pouco tempo depois desembocar na própria negação da existência das câmaras de gás (VIDAL-NAQUET, 1988). Já na área da filosofia, Luis Milman aponta que o revisionismo não apresenta problemas ao nível da compreensão da história, pois não se trata de uma visão alternativa, mas sim da construção de uma versão fictícia com efeitos políticos. Segundo o autor, os negacionistas “obrigam-nos não somente a refutá-los, mas a fazermos uma reflexão sobre a relevância do papel da história e da memória para a educação humanista" (MILMAN, $2000, \mathrm{n} / \mathrm{p})$.

No sentido de negar o conhecimento empiricamente verificável, negacionismo floresceu com o crescente aumento internacional do grau de desconfiança nas pesquisas científicas. O termo ficou inicialmente associado ao movimento antivacina (IDOETA, 2017), tendo como marco histórico a data de 26 de fevereiro de 1998, quando a prestigiada revista Lancet publicou um relato preliminar de pesquisa do médico Andrew Wakefield junto a 12 crianças que haviam desenvolvido comportamento autista e inflamação intestinal grave. Em função de o pesquisador ter encontrado vestígios do vírus do sarampo no corpo dos pesquisados, Wakefield e seus parceiros levantaram a hipótese de que havia um vínculo causal das enfermidades com a vacina MMR, usada para proteção contra sarampo, rubéola e caxumba, que havia sido aplicada em 11 das crianças estudadas. Quando vieram à tona a precariedade do estudo - apontada na obra Outra Sintonia (DONVAN; ZUCKER, 2017) - e a informação de que o pesquisador tinha conflito de interesses no caso, o Conselho Geral de Medicina do Reino Unido, em 2010, julgou Wakefield "inapto para o exercício da profissão", qualificando seu comportamento como “irresponsável”, “antiético" e "enganoso". A Lancet se retratou do estudo publicado, informando que as conclusões ali descritas eram "totalmente falsas" (IDOETA, 2017, $\mathrm{n} / \mathrm{p})$. 


\section{míDiA

\section{Movimentos antivacina}

A retratação do periódico e a desqualificação do pesquisador inglês, no entanto, não foram suficientes para conter o crescimento dos movimentos antivacina ao redor do mundo. Ao contrário, eles se transformaram em uma preocupação a mais para os países que se dispuseram a vacinar maciçamente suas populações quando do combate à pandemia da Covid-19. Um estudo conduzido por pesquisadores do Centro de Estudos e Pesquisas de Direito Sanitário (Cepedisa), da USP, em parceria com o Centro de Análise da Liberdade e do Autoritarismo (Laut) e com o Instituto Nacional de Ciência e Tecnologia em Democracia Digital (INCT.DD), apurou que os canais que divulgaram notícias falsas sobre a pandemia obtinham muito mais audiência que os canais dedicados a divulgar dados verdadeiros (MELLO, 2020). Ao todo, nas duas fases da pesquisa, foram estudados cerca de 23 mil vídeos postados no YouTube entre $1^{\circ}$ de fevereiro e 10 de maio de 2020.

$\mathrm{Na}$ primeira fase do estudo, as redes com grande circulação de informação sobre a doença tiveram quase três vezes mais visualizações do que as redes com dados verdadeiros sobre a Covid-19 - 73.429.098 visualizações, contra 27.712 .722 visualizações. O maior canal em que foram identificadas informações falsas é o Desperte - Thiago Lima, com 1,02 milhão de inscritos. O canal é 4,3 vezes maior que o do Ministério da Saúde (233 mil inscritos) e tem "temáticas conspiratórias religiosas, misticismo e de cunho geopolítico”. (MELLO, 2020, p. B5)

Atuações como a praticada pelo canal Desperte, entre outros dedicados a desinformar seus públicos, deram origem a uma linha de pesquisa denominada agnotologia pelo historiador americano Robert Neel Proctor, professor de História da Ciência na Universidade de Stanford. O neologismo deriva da expressão grega agnosis, equivalente a "não conhecimento", e passou a designar o estudo de políticas de produção da ignorância. Durante a pandemia, o pesquisador brasileiro Renan Leonel (2020) deu início ao estudo Viral agnotology: COVID-19 denialism amidst the pandemic in Brazil, United Kingdom, and United States (Agnotologia viral: negação da COVID-19 em meio à pandemia no Brasil, Reino Unido e Estados Unidos), financiado pela Social Science Research Council of New York (SSRC) em parceria com a Henry Luce Foundation. O 


\section{míDiA \\ ecD DiAno}

projeto de pesquisa tem por objetivo estudar os efeitos de curto e longo prazos da pandemia que atingiu o mundo em 2020.

Diethelm e Mackee (2009) apontam que os negacionistas no mundo digital além da pura e simples rentabilidade financeira decorrente de visualizações nas redes sociais - são movidos por uma ampla gama de motivações. Alguns, pela ganância fomentada por corporações industriais, como a do petróleo, negando a relação entre a queima de combustíveis fósseis e as mudanças climáticas; outros, por ideologia ou fé, o que os motiva a rejeitar tudo o que for incompatível com suas crenças fundamentais; havendo ainda os que o fazem por excentricidade e idiossincrasia, encorajados pela condição de celebridades que a mídia confere aos dissidentes de consensos estabelecidos. Camargo e Coeli (2020) recuperaram pesquisas na área para lembrar que os processos negacionistas apresentam ao menos cinco características básicas, todas observadas no período de debates públicos sobre a Covid-19. São elas:

1) identificação de conspirações; 2) uso de falsos experts; 3) seletividade, focalizando em artigos isolados que contrariam o consenso científico ("cherry-picking"); 4) criação de expectativas impossíveis para a pesquisa; e 5) uso de deturpações ou falácias lógicas. (CAMARGO; COELI, 2020, p. 2)

No Brasil, uma pesquisa desenvolvida pelo grupo União Pró-Vacina, composto por pesquisadores do Instituto de Estudos Avançados da unidade da USP de Ribeirão Preto (SP), procura monitorar grupos antivacina no Facebook (RAFAEL, 2020). No estudo, os pesquisadores observaram três eixos principais entre os divulgadores de conteúdos falsos: o primeiro seria o eixo ideológico - o predominante - formado por pessoas que realmente acreditam nas teorias antivacina e transformam suas vidas em uma missão a serviço daquela causa. O segundo eixo reúne os que possuem interesse comercial, maciçamente presentes no YouTube, onde buscam obter audiência para lucrar com as visualizações. E o terceiro, de viés político, teria crescido com a politização e polarização com a pandemia.

O fortalecimento dos grupos negacionistas tem imposto questionamentos a algumas regras do jornalismo, como a de relatar objetivamente o acontecimento noticiado. Dois fenômenos recentes, um deles com repercussão mundial, bem ilustram o 


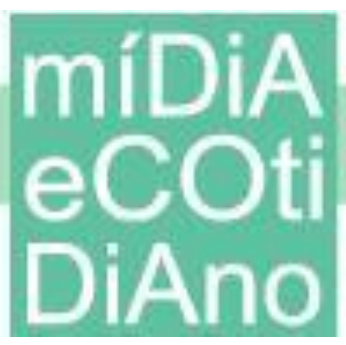

problema. O primeiro ocorreu quando as redes de televisão CBS, ABC e NBC, dos EUA, interromperam abruptamente a transmissão de um pronunciamento do então presidente Donald Trump, que acusava, sem provas, ter havido fraude nas eleições que prenunciavam sua derrota, em 5 de novembro de 2020. O outro decorre de uma enxurrada de críticas que o jornal Folha de S. Paulo recebeu ao noticiar, objetiva e acriticamente, que o presidente Jair Bolsonaro, falando em audiência remota na abertura dos trabalhos da ONU, dizia não haver desmatamento sistemático da Floresta Amazônica. No caso brasileiro, o jornal foi acusado de apenas reproduzir o pronunciamento do mandatário, sem apontar em seu título que se tratava de uma mentira empiricamente verificável.

Já em 2016, ao comentar o resultado das eleições norte-americanas, o professor Robert P. Crease, do Departamento de Filosofia da Stony Brook University, afirmava em artigo para a revista Physics World que negacionistas vinham ganhando espaço aceleradamente junto ao poder político. De acordo com este historiador da ciência, o fenômeno representa uma ameaça ao próprio desenvolvimento social, pois os negacionistas se capacitam a influenciar políticas públicas contrárias ao conhecimento científico. Crease chega a propor sanções legais aos propagadores de inverdades, uma vez que "escolhas erradas serão inevitavelmente feitas se as informações científicas não forem incorporadas a tais decisões" (CREASE, 2016, n/p, tradução nossa).

Muito em função da estrutura e da onipresença das redes sociais digitais no mundo contemporâneo, Leonel (2020) assegura que cientistas, divulgadores científicos e jornalistas focados na ciência passaram a ter um trabalho adicional nos últimos tempos: além de comunicar o conhecimento científico, agora precisam também comunicar claramente aos seus públicos o que não é ciência. Essa nova tarefa justifica, por si só, a necessidade de se implementarem estudos focados na confluência do binômio comunicação e negacionismo.

\section{Negacionismo e áreas de estudo}

Os textos recuperados no Portal de Periódicos da Capes permitiram a elaboração de categorias organizadas em quatro tabelas para este trabalho. A primeira é dedicada aos autores e respectivos títulos de seus estudos, oferecendo também informações sobre o número de citações que obtiveram e os centros de pesquisa aos quais pertencem. As outras 


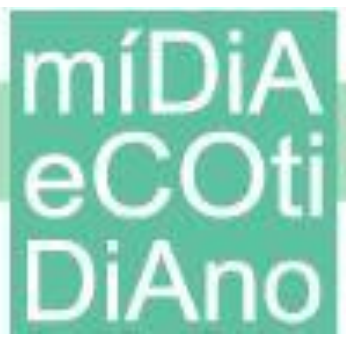

três tabelas apontam a presença do verbete negacionismo nas áreas de estudo às quais pertencem os autores, a saber: História, Sociologia e Ciência da Informação. A seguir, a primeira das tabelas:

Tabela 1: Autores, obras, área e centro de estudo

\begin{tabular}{|c|c|c|c|}
\hline No. & Autor / Título / Editora /Ano & Área & $\begin{array}{c}\text { Citações } \\
\text { e IES }\end{array}$ \\
\hline 1 & $\begin{array}{l}\text { MARTIN VICENTE, Maximiliano. História e comunicação na nova } \\
\text { ordem internacional. (Editora Unesp, 2009) }\end{array}$ & $\begin{array}{l}\text { História e } \\
\text { comunicação }\end{array}$ & $\begin{array}{c}66 \\
\text { UNESP }\end{array}$ \\
\hline 2 & $\begin{array}{l}\text { CALDEIRA NETO, Odilon. Memória e justiça: o negacionismo e a } \\
\text { falsificação da história (Antíteses, 2009) }\end{array}$ & História & $\begin{array}{c}12 \\
\mathrm{UEL}\end{array}$ \\
\hline 3 & $\begin{array}{l}\text { CASTRO, Ricardo Figueiredo de. O negacionismo do holocausto: } \\
\text { pseudo história e história pública (Resgate, v. XXII, n. 28, 2014) }\end{array}$ & História & $\begin{array}{c}2 \\
\text { UFRJ }\end{array}$ \\
\hline 4 & $\begin{array}{l}\text { GOMES, Aguinaldo Rodrigues. Machocracia, negacionismo } \\
\text { histórico e violência no Brasil contemporâneo (Ñanduty, v. 7, 2019) }\end{array}$ & $\begin{array}{l}\text { Ciências } \\
\text { Sociais }\end{array}$ & $\begin{array}{c}1 \\
\text { UFMGS }\end{array}$ \\
\hline 5 & $\begin{array}{l}\text { SILVA, Francisco Carlos Teixeira da. Corpo e Negacionismo: a } \\
\text { Novilíngua do Fascismo na Nova República, Brasil 2013/2019 } \\
\text { (Locus - Revista de História, v. 25, n. 2, 2019) }\end{array}$ & $\begin{array}{l}\text { Ciências } \\
\text { Sociais }\end{array}$ & $\begin{array}{c}0 \\
\mathrm{UFJF}\end{array}$ \\
\hline 6 & $\begin{array}{l}\text { SANTOS D'AMORIM, Karen Isabelle; REIS CRUZ, Rúbia } \\
\text { Wanessa dos; CORREIA, Anna Elizabeth Galvão Coutinho. O uso } \\
\text { dos blogs de ciência no campo da ciência da informação no Brasil e } \\
\text { seus papéis na cultura científica (Brazilian Journal of Information, v. } \\
\text { 14, n. 2, 2020) }\end{array}$ & $\begin{array}{l}\text { Ciência da } \\
\text { Informação e } \\
\text { Comunicação }\end{array}$ & $\begin{array}{c}0 \\
\text { UFPE }\end{array}$ \\
\hline
\end{tabular}

Fonte: elaborado pelos autores.

A Tabela 1 aponta autores, periódicos/livro, local de publicação, área de estudo na qual está inserido o trabalho e as instituições de ensino e pesquisa às quais pertencem os pesquisadores. Na tabela, os textos estão ordenados segundo o número de citações registradas, à época do levantamento de dados, na plataforma Google Citations.

De todos, a publicação que registra o maior número de citações é o livro História e Comunicação na Nova Ordem Internacional (Editora Unesp, 2009), do livre-docente Maximiliano Martin Vicente, doutor em História Social pela Universidade de São Paulo (USP), com 66 citações. Em segundo lugar, com 12 citações, aparece o artigo Memória e 


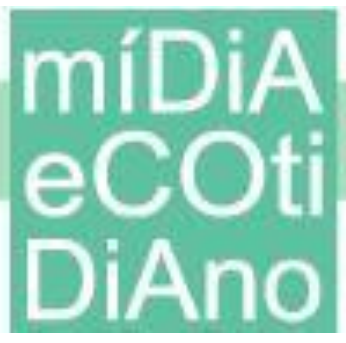

Justiça: o negacionismo e a falsificação da história, do historiador Odilon Caldeira Neto, da Universidade Federal de Juiz de Fora (UFJF), publicado na revista Antíteses, do Programa de Pós-Graduação em História Social, da Universidade Estadual de Londrina (UEL).

O terceiro trabalho recuperado, O negacionismo do holocausto: pseudo história e história pública, possuía apenas duas citações à época do levantamento. Trata-se de um artigo do professor Ricardo Figueiredo de Castro, doutor em História Social pela Universidade Federal do Rio de Janeiro (UFRJ), onde leciona. O texto foi publicado na revista Resgate, uma produção interdisciplinar das áreas de Ciências Humanas e Artes, da Universidade Estadual de Campinas (Unicamp).

O quarto texto, Machocracia, negacionismo histórico e violência no Brasil, contava com apenas uma citação segundo apontou o Google Citations. Publicado na revista $\tilde{N} a n d u t y$, do Departamento de Antropologia da Universidade Federal da Grande Dourados (UFGD), seu autor, Aguinaldo Rodrigues Gomes, é doutor em Educação pela Universidade Estadual de Campinas (Unicamp) e leciona disciplinas ligadas à História, na Universidade Federal de Mato Grosso do Sul.

O quinto texto refere-se ao artigo Corpo e Negacionismo: a Novilíngua do Fascismo na Nova República, Brasil 2013/2019, do historiador Francisco Carlos Teixeira da Silva, doutor em História pela Universidade Livre de Berlim. O trabalho foi publicado na revista Locus, periódico focado na área de História com contribuições de outras disciplinas de Ciências Humanas. A revista é uma publicação do Departamento e do Programa de Pós-Graduação em História, da Universidade Federal de Juiz de Fora (UFJF).

Já o sexto trabalho recuperado, $O$ uso dos blogs de ciência no campo da ciência da informação no Brasil e seus papéis na cultura científica, sem citação no Google Citations, é o mais recente de todos. É assinado pelas pesquisadoras Karen Isabelle Santos D’Amorim; Rúbia Wanessa dos Reis Cruz; e Anna Elizabeth Galvão Coutinho Correia. Entre as autoras, Correia é graduada em Biblioteconomia, com doutorado em Ciência da Informação pela Universidade Federal de Minas Gerais (UFMG), onde leciona; as outras duas possuem mestrado e doutorado em andamento em Ciência da Informação, na Universidade Federal de Pernambuco (UFPE). O trabalho foi publicado na revista Brajis, 


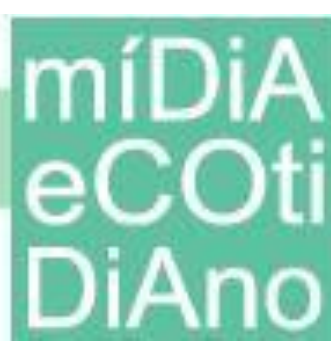

acrônimo para Brazilian Journal of Information Studies: Research trends, periódico editado Faculdade de Filosofia e Ciências, da Universidade Estadual Paulista (Unesp), campus Marília.

Três dos seis trabalhos recuperados pertencem ao campo da História, enquanto dois foram produzidos no campo da Sociologia e um último, em Ciências da Informação. Em comum, todos levam a assinatura de pesquisadores ligados a universidades públicas, com destaque às instituições federais. Majoritariamente, foram produzidos por estudiosos do sexo masculino, havendo em um dos trabalhos a parceria entre três autoras, com a liderança de uma docente originalmente formada na área da Biblioteconomia.

Tabela 2: Negacionismo no campo da História

(continua)

Texto

“[...] responde à predominância de um pensamento pós-modernista no qual, a princípio, se aceitam todas as versões e interpretações em função da sua fragmentação. Diante desse quadro, a história propõe alguns pontos de vista para entender melhor os desdobramentos da história nessas últimas décadas". (MARTIN VICENTE, 2009, p. 84)

"O negacionismo surge como uma tentativa intolerante e predatória da memória da Segunda Guerra Mundial, e consiste atualmente numa das maiores expressões do anti-semitismo da extrema-direita. É uma prática de falsificação histórica e os autores se colocam como pesquisadores interessados em buscar a verdade histórica". (CALDEIRA NETO, 2009, p. 1107)

"O Negacionismo do Holocausto é atualmente um dos principais elementos de coesão ideológica e manutenção das forças de atração que mantém unida a nebulosa fascista contemporânea e ajuda a definir sua identidade. O Negacionismo do Holocausto não é uma perspectiva historiográfica legítima a se dedicar a revisar os postulados históricos do holocausto, mas sim um instrumento de ação ideológica a serviço de grupos 
Tabela 2: Negacionismo no campo da História

(continuação)

3 políticos radicais em sua grande maioria de extrema-direita”. (CASTRO, 2014, p. 8-9)

Fonte: Elaborado pelos autores (2021).

Conforme apontam os excertos acima, no único trabalho produzido no formato livro indexado no Portal de Periódicos, a referência a negacionismo surge na página 84 , como observado na Tabela 2, porém associada ao revisionismo histórico. A obra em questão não se ocupa em debater conceitos em torno do tema, nem em registrar o crescimento de doutrinas ultradireitistas no mundo contemporâneo. O interesse do autor é investigar as aproximações que existem entre os registros produzidos pelo campo da história e as práticas contemporâneas de comunicação social, particularmente nos veículos impressos do sistema de mídia. Transitando entre os dois territórios, o autor aponta que os historiadores consideram os comunicadores demasiadamente superficiais em suas análises, enquanto os jornalistas ficam incomodados com "a falta de atualização e preocupação dos historiadores com os episódios recentes” (MARTIN VICENTE, 2009, p. 16).

Buscando resgatar para estudo de caso a cobertura do atentado de 11 de setembro de 2001 nos EUA, com o ataque às torres gêmeas, o trabalho pondera que história e jornalismo têm uma importante função socializadora a cumprir, cada qual ao seu modo. Devido aos objetivos da obra, o estudo apresentado não faz menção ao crescimento dos movimentos fascistas no mundo contemporâneo, nem se apega às questões de gênero, etnia e exclusões sociais presentes nos discursos de ódio que caracterizam os negacionistas.

Já no texto 2, o artigo se apega ao trabalho do historiador e intelectual francês Pierre Vidal-Naquet (1930-2006) para fazer um resgate de como o fenômeno do negacionismo teria surgido. No texto, é possível observar que a definição de negacionismo usada por Caldeira Neto $(2009$, p. 1107) está ligada a um "atentado à memória da Segunda Guerra Mundial”. O autor promove uma discussão sobre como o negacionismo entrou no Brasil e os caminhos percorridos no país até os dias atuais. De 


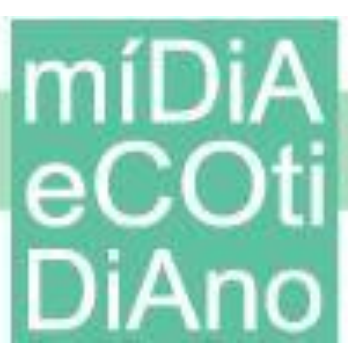

acordo com o trabalho, as primeiras discussões sobre negacionismo no país começaram no fim da década de 1970, quando jornais de grande circulação publicaram comentários sobre o livro Hitler's War (Editora Viking Press, 1977), de David Irving, que, apesar de não ser totalmente negacionista, sugeria que Adolf Hitler não teve participação no Holocausto.

No Brasil - aponta o trabalho - o movimento de teses negacionistas chegou no final da década de 1980, momento de eclosão da luta por eleições diretas e o fím da ditadura militar. É neste contexto que surge, segundo o autor, o livro negacionista brasileiro mais famoso: Holocausto: judeu ou alemão? Nos bastidores da mentira do século (1987), de Siegfied Ellwanger, brasileiro descendente de alemães que foge para o Rio Grande do Sul e monta uma editora. $\mathrm{O}$ trabalho não menciona ameaças ao regime democrático nem questões de gênero ou negacionismo do conhecimento científico.

No terceiro texto, o autor faz um mergulho no conceito de negacionismo, relacionando-o apenas ao Holocausto. Questões como ideologia de gênero e movimentos antivacina estão ausentes do escopo do trabalho. O artigo aponta, no entanto, que o negacionismo, diferentemente de quando surgiu, está totalmente ligado a correntes de movimentos de extrema direita e de pessoas que compartilham ideias do fascismo. Para o autor, negar o Holocausto não é apenas uma tentativa de revisão da história ou de reconstrução de memória, mas sim um mecanismo de dominação ideológica e política. Focado na historiografia, o texto não aborda questões de identidade sexual ou negacionismo da ciência, mas adverte para o desrespeito aos Direitos Humanos e para o recurso às teorias conspiratórias engendradas pela extrema direita.

\section{Tabela 3: Negacionismo na Sociologia}

(continua)

\begin{tabular}{cc}
\hline Texto & Definição na área de Ciências Sociais \\
\hline 4 & "O negacionismo é ainda um termo pouco conhecido pelos brasileiros, ganhou maior \\
& visibilidade a partir das falas de políticos e eleitores do país no último pleito sufragista \\
& que em seus discursos buscaram anular as origens históricas da desigualdade \\
& econômico-social a partir da negação dos processos de exclusão historicamente
\end{tabular}


constituídos no país. Constitui-se num movimento que por razões religiosas, conspiracionistas ou com vistas a beneficiar certos

Tabela 3: Negacionismo na Sociologia

(continuação)

4 grupos rejeitam teses amparadas em estudos científicos e documentados, apoiandose em ideias controversas e de pouca confiabilidade" (GOMES, 2019, p. 150).

5 "Aqueles que promovem discursos de ódio contra grupos sociais, raciais, regionais ou de gênero e recusam a história do passado recente, incluindo do Regime CivilMilitar de 1964" (SILVA, 2019, p. 307).

Fonte: Elaborado pelos autores (2021).

Os textos 4 e 5, cujos excertos se encontram anotados na Tabela 3, localizam-se no campo das Ciências Sociais e apresentam uma outra experiência relacionada ao negacionismo, associando a prática ao discurso político da extrema direita que, apoiandose em argumentos preconceituosos, procura colocar grupos minoritários à margem da sociedade. O objetivo dos conservadores radicais, associados ao fascismo, seria doutrinar a população mais jovem que se identifica com esse pensamento, adotando discurso de ódio, rejeitando evidências históricas e propondo uma nova visão de mundo. Entre os textos recuperados no portal da Capes, são estes os trabalhos mais politizados, em especial por atribuírem nomes a personagens atualmente identificados com as práticas negacionistas e fazerem referência à propagação de mentiras através das tecnologias de informação e comunicação.

No texto 4, o autor propõe uma reflexão sobre o império da falocracia presente na política brasileira, buscando estabelecer as relações existentes entre o neologismo e o desrespeito aos direitos humanos e à diversidade social no Brasil contemporâneo. $\mathrm{O}$ artigo busca apontar "como o machismo, a misoginia e a lgbtfobia têm influenciado a precarização e eliminação de vidas com base na discriminação por marcadores de gênero, etnia e classe social" (GOMES, 2019, p. 147). O trabalho se dedica, a partir da análise de discurso, a analisar pronunciamentos do presidente que acabara de ser eleito e que viria a 


\section{míDiA

ser reconhecido como um dos expoentes brasileiros mais identificados com a doutrina fascista (FINCHELSTEIN, 2020).

A denúncia do autoritarismo e misoginia contidos nos discursos bolsonaristas também estão presentes no texto 5, no qual o autor recorre ao conceito de "novilíngua" criado pelo professor polonês Victor Klemperer (1881-1960), da área de filologia semântica, para descrever o vocabulário nazista empregado na perseguição a judeus na Alemanha de Hitler. A expressão é também utilizada na obra literária 1984, de George Orwell, sendo marcada por "eufemismo, cinismo e covardia" (SELIGMANN-SILVA, 2000) para designar a linguagem de um estado totalitário objetivando manipular e influenciar audiências.

O trabalho foca igualmente discursos do então eleito presidente Bolsonaro e de sua agremiação política de então, o Partido Social Liberal (PSL), bem como movimentos, personagens e atores políticos de extrema direita que rejeitam a democracia representativa, promovem discursos de ódio e não aceitam o consenso de ter existido uma ditadura civil-militar na história recente do país. O trabalho aponta que as doutrinas ultradireitistas vêm crescendo com a mesma intensidade em países europeus, conforme apuram Caiani e Susánszki (2020) em artigo que associa esse crescimento às ferramentas do universo on-line.

Tabela 4: Negacionismo na Ciência da Informação

\begin{tabular}{cc}
\hline Texto & Definição nas Ciências da Informação \\
\hline \multirow{3}{*}{6} & "McIntyre (2018) citado por Araújo (2020, p. 5 e 6) elenca fatores que conduziram ao \\
& que se conhece hoje por 'pós-verdade', entre eles: o negacionismo científico, o auge \\
& das redes sociais e a relativização da verdade promovida pelo pós-modernismo. Essa \\
& condição atual, associada à massificação das redes sociais e os fenômenos inter- \\
& relacionados à desinformação, agora se coloca diante de uma era marcada pela \\
& explosão desinformacional." (SANTOS-D'AMORIM; CRUZ; CORREIA, 2020, p. \\
27)
\end{tabular}

Fonte: elaborado pelos autores. 
O mais recente dos artigos recuperados, com excerto reproduzido na Tabela 4, foi publicado em 2020. Nele, as autoras chegam a 88 blogs utilizados para a divulgação do conhecimento científico na área de Ciência da Informação, partindo de autores como o filósofo britânico Alasdair McIntyre (2001), autor de Depois da Virtude, para debater a relativização da verdade e a hegemonia das redes digitais na polifonia do mundo contemporâneo. Embora não utilize a expressão negacionismo entre suas palavras-chave, o artigo adverte para o fomento de sucessivas tentativas de refutação de teorias científicas, não em função da quebra de paradigmas, mas a partir da criação de "teorias conspiratórias, pautadas em convicções pessoais, interesses políticos e econômicos de grandes grupos, cada vez mais ampliadas pelo fenômeno das câmaras de eco e filtros bolha, o que caracteriza a conjuntura atual marcada pela desinformação e pela pósverdade." (SANTOS-D'AMORIM; CRUZ; CORREIA, 2020, p. 26-27).

$\mathrm{O}$ artigo registra a diminuição, ao longo dos últimos 15 anos, de blogs focados em Ciência da Informação, à medida que seus autores - geralmente estudantes da área engajam-se em redes oficiais de pesquisa e já não encontram tempo para atualizá-los. O trabalho não entra em discussões a respeito do negacionismo científico como estratégia de ação de movimentos político-ideológicos. Expressões como "direita", "fascismo" ou "gênero" não são registradas ao longo do documento, inexistindo, portanto, reflexões político-ideológicas indispensáveis àquele momento histórico, caracterizado pela ascensão de movimentos conservadores e permeado pela circulação de fake news.

\section{Considerações finais}

O percurso adotado na produção deste trabalho evidenciou que o tema investigado é pouco presente na principal plataforma brasileira para recuperação de artigos acadêmicos e pesquisas científicas publicados em língua portuguesa. Embora negacionismo não seja expressão de uso tão recente, foi apenas no ano de 2020 que ganhou domínio popular, a ponto de figurar como principal manchete em um jornal diário, mesmo assim associada à cobertura política, embora se referisse ao descrédito no conhecimento científico.

A expressão apareceu em apenas seis textos recuperados junto ao Portal de Periódicos da Capes, datados de 2009 a 2020, o que pressupõe média anual inferior a 0,5 


\section{míDiA

texto. Os dados apurados ainda indicam a predominância de instituições públicas voltadas à pesquisa do fenômeno, na maioria das vezes associado à história. Percebe-se que, na área da Comunicação Social ou de estudos de mídia, negacionismo praticamente inexiste, o que indica um universo a ser investigado, mesmo porque a principal estratégia contemporânea para a divulgação de inverdades ou teses negacionistas são exatamente as redes sociais digitais.

Estudos que possam derivar ou serem motivados a partir do resultado deste nosso trabalho seriam extremamente oportunos nos dias atuais, mesmo porque o negacionismo vem se instalando, cada vez mais, em instâncias do poder político. O combate a esta prática - um trabalho a mais para cientistas, divulgadores científicos e jornalistas, como vimos anteriormente - será fundamental para evitar que o obscurantismo, o charlatanismo e mistificações comprometam o grau de liberdade, justiça social e democracia do qual as sociedades modernas não podem prescindir.

\section{Referências}

CALDEIRA NETO, O. Memória e justiça: o negacionismo e a falsificação da história. Antíteses, v. 2, n. 4, p. 1097-1123, jul./dez., 2009. Disponível em: http://www.uel.br/revistas/uel/index.php/antiteses/article/view/2507/4026. Acesso em: $7 \mathrm{dez}$. 2020.

CAMARGO, K. R. de; COELI, C. M. A difícil tarefa de informar em meio a uma pandemia. Physis: Revista de Saúde Coletiva, v. 30, n. 2, p. 1-5, 2020.

CASTRO, R. F. de. O negacionismo do holocausto: pseudo história e história pública. Resgate, v. XXII, n. 28, p.5-12, jul./dez., 2014.

CREASE, R. P. Fighting science denial. Physics World, 15 sep. 2016. Disponível em: https://physicsworld.com/a/fighting-science-denial/. Acesso em: 12 dez. 2020.

DIETHELM, P.; MCKEE, M. Denialism: what is it and how should scientists respond? European Journal of Public Health, v. 19, n. 1, p. 2-4, 2009.

DONVAN, J.; ZUCKER, C. Outra Sintonia: A história do autismo. São Paulo: Companhia das Letras, 2017. 
DUNKER, C. O negacionismo como arma de destruição durante a pandemia. [Entrevista concedida a Bertha Maakaroun]. Estado de Minas, Belo Horizonte, n/p, 24 jul. 2020. Disponível em: $\quad$ https://www.em.com.br/app/noticia/pensar/2020/07/24/interna_pensar,1169615/onegacionismo-como-arma-de-destruicao-durante-a-pandemia.shtml. Acesso em: 20 dez. 2020.

FINCHELSTEIN, F. "Bolsonaro é o populista que mais se aproximou do fascismo na história". [Entrevista concedida a Rosana Pinheiro-Machado] The Intercept Brasil, n/p, 7 jul. 2020. Disponível em: https://theintercept.com/2020/07/07/bolsonaro-populista-fascismo-entrevistafederico-finchelstein/. Acesso em: 2 mai. 2021.

FRANCO, M. L. P. B. Análise de conteúdo. 4. ed. Brasília: Líber Livro, 2012.

GOMES, A. R. Machocracia, Negacionismo Histórico e Violência no Brasil Contemporâneo. Nanduty, v. 17, n. 10, p. 146-158, 2019.

GOMES, W. A pandemia como um problema de comunicação política. Cult, São Paulo, n/p, 26 mar. 2021. Disponível em: https://revistacult.uol.com.br/home/pandemia-como-problema-decomunicacao-politica/. Acesso em: 23 abr. 2021.

GOOGLE TRENDS. Negacionismo Trends. Disponível em: https://trends.google.com.br/trends/explore?date=today\%205$\mathrm{y} \& \mathrm{geo}=\mathrm{BR} \& \mathrm{q}=\% 2 \mathrm{Fm} \% 2 \mathrm{~F} 026 \mathrm{bq} 09$. Acesso em: 06 jan. $2021^{\mathrm{a}}$

GOOGLE TRENDS. Denialism Trends. Disponível em: https://trends.google.com.br/trends/explore?q=denialism. Acesso em: 06 jan. 2021b

HISTERIA, gripezinha e mimimi: o discurso de Bolsonaro após um ano de pandemia. TV Folha, São Paulo, 2021. Disponível em: https://www.youtube.com/watch?v=o-Qoib3S1rA. Acesso em: 25 mar. 2021.

IDOETA, P. A. A história que deu origem ao mito da ligação entre vacinas e autismo. BBC News Brasil, São Paulo, n/p, 24 jul. 2017. Disponível em: https://www.bbc.com/portuguese/geral40663622. Acesso em: 20 dez. 2020.

LEONEL, R. Negacionismo científico: a produção política e cultural de desinformação. [Entrevista concedida a Karina Toledo]. Agência Fapesp (online), São Paulo, n/p, 02 set. 2020. Disponível em: https://agencia.fapesp.br/negacionismo-cientifico-a-producao-politica-e-culturalde-desinformacao/34028/. Acesso em: 10 out. 2020.

LUHMANN, N. A realidade dos meios de comunicação. Trad.: Ciro Marcondes Filho. São Paulo: Paulus, 2005. 
MARICATO, J. de M. Dinâmica das relações entre Ciência e Tecnologia: estudo Bibliométrico e Cientométrico de múltiplos indicadores de artigos e patentes em biodiesel. 2010. Tese de Doutorado. Escola de Comunicações e Artes. Universidade de São Paulo.

MARTIN VICENTE, M. História e comunicação na nova ordem internacional. São Paulo: Editora Unesp, 2009.

MCINTYRE, A. Depois da virtude: Um estudo em Teoria Moral. Bauru (SP): Edusc, 2001.

MEDITSCH, E. Journalism as a form of knowledge. Biblioteca On Line de Ciências da Comunicação. Covilhã (Portugal), 1997. Disponível em: http://www.bocc.ubi.pt/pag/meditscheduardo-journalism-as-a-form-of-knowledge.pdf. Acesso em 10 jan. 2020.

MELLO, P. C. Canais de fake news no YouTube têm quase 3 vezes mais audiência. Folha de $\mathbf{S}$. Paulo, São Paulo, 21 mai. 2020. Saúde, B5. Disponível em: https://www1.folha.uol.com.br/equilibrioesaude/2020/05/canais-de-fake-news-sobre-covid-19no-youtube-sao-vistos-quase-3-vezes-mais-que-os-de-dados-reais.shtml. Acesso em: 28 mai. 2020.

MILMAN, L. Negacionismo: Génese e desenvolvimento do extermínio conceitual, 2000. In:

MILMAN, L.; VIZENTINI, P. F. (Org). Neonazismo, Negacionismo e Extremismo Político. Porto Alegre: UFRGS (Edição Online), 2002, n/p. Disponível em: http://www.derechos.org/nizkor/brazil/libros/neonazis/cap9.html. Acesso em: 03 nov. 2020.

NEGACIONISMO. In: Dicionário Online de Português. Porto: 7Graus, 2020a. Disponível em: https://www.dicio.com.br/negacionismo/. Acesso em: 12 jan. 2021.

NEGACIONISMO. In: Dicionário Porto Editora. Porto: Porto Editora, 2020b. Disponível em: https://www.infopedia.pt/dicionarios/lingua-portuguesa/negacionismo. Acesso em: 12 jan. 2021.

"RESTAM poucos dias para o negacionismo". O Estado de S. Paulo, São Paulo, 27 nov., 2020. Disponível https://www.facebook.com/estadao/photos/a.124486140899790/4942522985762724/. Acesso em: 10 dez. 2020.

RAFAEL, J. H. Pesquisadores analisam avanço de grupos antivacina em plena pandemia. [Entrevista concedida a Maria Fernanda Ziegler]. Agência Fapesp (online), São Paulo, n/p, 22 dez. 2020. Disponível em: https://agencia.fapesp.br/pesquisadores-analisam-avanco-de-gruposantivacina-em-plena-pandemia/34890/. Acesso em: 23 dez. 2020.

SANTOS-D'AMORIM, K. I.; CRUZ, R. W dos R.; CORREIA, A. E. G. C. O uso dos blogs de ciência no campo da Ciência da Informação no Brasil e seus papéis na cultura científica. Brazilian Journal of Information Studies: Research trends, v. 14, n. 2, abr./jun., p. 24-47, 2020. 
Disponível

em:

https://www.researchgate.net/publication/342611670_O_uso_dos_blogs_de_ciencia_no_campo _da_Ciencia_da_Informacao_no_Brasil_e_seus_papeis_na_cultura_cientifica. Acesso em: $5 \mathrm{dez}$. 2020.

SELIGMANN-Silva, M. A língua adulterada. Folha de S. Paulo, São Paulo, 19 nov. 2000. Caderno Mais, p. 10-11. Disponível em: https://www1.folha.uol.com.br/fsp/mais/fs1911200007.htm. Acesso em: 5 ago. 2020.

SILVA, F. C. T. da. Corpo e negacionismo: a novilíngua do fascismo na Nova República, Brasil 2013/2019. Locus - Revista de História, v. 25, n. 2, p. 307-332, 2019.

SOUSA, J. P. de. Uma breve história do jornalismo no ocidente. Biblioteca On Line de Ciências da Comunicação. Covilhã (Portugal), 2008. Disponível em: http://www.bocc.ubi.pt/pag/sousajorge-pedro-uma-historia-breve-do-jornalismo-no-ocidente.pdf . Acesso em: 20 jan. 2019.

VIDAL-NAQUET, P. Os assassinos da memória: um Eichmann de papel e outros ensaios sobre o revisionismo. Trad.: Marina Appenzeller. Campinas (SP): Papirus, 1988. 